http://dx.doi.org/10.32929/2446-8355.2021v30n2p166-177

\title{
EFFECTS OF PLANTING DATES ON GROWTH AND NUTRIENT ACCUMULATION OF CARROTS IN THE BRAZILIAN SEMI-ARID
}

\author{
Victor Emmanuel de Vasconcelos Gomes ${ }^{1 *}$, Leilson Costa Grangeiro ${ }^{2}$, Núbia Marisa \\ Ferreira $^{3}$, Rodolfo Rodrigo de Almeida Lacerda ${ }^{3}$, Antônio Fabrício de Almeida ${ }^{3}$, Jorge Luiz \\ Alves da Silva ${ }^{4}$

\footnotetext{
${ }^{1}$ Mestrando, Programa de Pós-graduação em Fitotecnia, Universidade Federal Rural do Semi-árido, MossoróRN. *E-mail do autor correspondente: devasconcelosgomes.1@ osu.edu

${ }^{2}$ Professor Titular, Programa de Pós-graduação em Fitotecnia, Universidade Federal Rural do Semi-árido, Mossoró-RN.

${ }^{3}$ Doutorando(a), Programa de Pós-graduação em Fitotecnia, Universidade Federal Rural do Semi-árido, Mossoró-RN.

${ }^{4}$ Graduando em Agronomia, Universidade Federal Rural do Semi-árido, Mossoró-RN.
}

\section{Recebido: 27/03/2021; Aceito: 01/11/2021}

\begin{abstract}
Fertilization plays an important role on carrot's yield, root quality, storage, plant growth and on the environment. It was aimed to evaluate the plant growth and macronutrients accumulation of carrot cultivars as a function of two planting dates, under high temperatures in the Brazilian semi-arid. The experiments were carried out in randomized blocks design, with ten treatments and four repetitions. Treatments consisted of ten carrot cultivars sowed in two Planting dates. The characteristics that were evaluated were: plant growth (plant height, number of leaves, plant dry matter accumulation, mean fresh mass of the root) and macronutrient accumulation (N, P, K, Ca and Mg) in plant, leaves and root. Plant's mean height ranged from $42.53 \mathrm{~cm}$ (Melinda) to $49.25 \mathrm{~cm}$ (Nativa); the highest plant dry matter was obtained by BRS Planalto (12.36 g) and Kuronan (12.18 g); the mean number of leaves was the lowest in Melinda and Nativa: 8.64 and 7.64 leaves plant ${ }^{-1}$. The root's fresh weight had a significant decrease among the planting dates for the Brasília, Francine and Suprema cultivars. The nutrient accumulation varied accordingly to the planting date and cultivar.
\end{abstract}

Key words: Daucus carota L. Genotypes. Macronutrients. Adaptability. Efficiency.

\section{EFEITOS DA ÉPOCA DE PLANTIO NO CRESCIMENTO E ACÚMULO DE NUTRIENTES EM CENOURAS NO SEMIÁRIDO BRASILEIRO}

RESUMO: A fertilização desempenha um papel importante no rendimento, qualidade da raiz, armazenamento, crescimento de plantas de cenoura e no meio ambiente. Objetivou-se avaliar o crescimento das plantas e o acúmulo de macronutrientes de cultivares de cenoura em função de duas épocas de plantio, sob altas temperaturas no semi-árido brasileiro. Os experimentos foram realizados em delineamento de blocos casualizados, com dez tratamentos e quatro repetições. Os tratamentos consistiram em dez cultivares de cenoura semeadas em duas épocas de plantio. As características avaliadas foram: crescimento da planta (altura da planta, 
número de folhas, acúmulo de matéria seca da planta, massa fresca média da raiz) e acúmulo de macronutrientes $(\mathrm{N}, \mathrm{P}, \mathrm{K}, \mathrm{Ca}$ e $\mathrm{Mg}$ ) na planta, folhas e raiz. A altura média da planta variou de 42,53 cm (Melinda) a 49,25 cm (Nativa); a maior matéria seca da planta foi obtida por BRS Planalto (12,36 g) e Kuronan (12,18 g); o número médio de folhas foi o menor em Melinda e Nativa: 8,64 e 7,64 folhas planta ${ }^{-1}$. O peso fresco da raiz diminuiu significativamente entre as épocas de plantio para as cultivares Brasília, Francine e Suprema . $\mathrm{O}$ acúmulo de nutrientes variou de acordo com a época de plantio e a cultivar.

Palavras-chave: Daucus carota L. Genótipos. Macronutrientes. Adaptabilidade. Eficiência.

\section{INTRODUCTION}

In 2015, 780.7 thousand tons of carrots were harvested in Brazil, and the cultivated area with this vegetable in that year was 23.1 thousand hectares. The average yield of the carrot crop in Brazil is about 33.8 tons ha $^{-1}$, which is below the crop's full potential, estimated between 100 and $120 \mathrm{t} \mathrm{ha}^{-1}$. Amongst the reasons for this subpar performance are the lack of climatic zoning and the inadequate choice of genotypes, population density, fertilization, irrigation and pest control (ANUÁRIO BRASILEIRO DE HORTALIÇAS - ABH, 2016).

In regions with high temperatures, the carrot cultivation is negatively affected, since this climatic trait tends to reduce root's size and pigmentation and, consequently, yield and quality. In some of the Brazilian States, the carrot production does not even supply the domestic demand, as per example in Rio Grande do Norte State, in which virtually all of the carrots that are commercialized come from Bahia State, which increases the costs of this product in the local market (TEÓFILO et al., 2009).

Regarding the mineral nutrition of this crop, fertilizers represent about $45 \%$ of the total production costs of carrots (CENTRO DE ESTUDOS AVANÇADOS EM ECONOMIA APLICADA - CEPEA, 2010). Besides the economic importance, fertilization plays an important role on yield (MENEGAZZO, 2010), on root quality (Luz et al., 2009), on storage (MÜLLER, 1982), on environment and on the profits from the cultivation.

Research that evaluate how the planting date affects plant growth and nutrient accumulation in regions with high temperatures and the semi-arid, however, are scarce.

It is presumed that the different cultivars, due to their genetic traits, and the planting date, due to variations in environmental factors, might interact, exerting influence on nutrient accumulation and transportation in carrot plants and, consequently, on plant's growth.

The aim of this work is to evaluate plant growth and accumulation of macronutrients in ten carrot cultivars as a function of two different planting dates in Mossoró, Rio Grande do Norte.

\section{MATERIAL AND METHODS}

\section{Location and Description of the Study Area}


The experiments were carried out at the Rafael Fernandes farm, belonging to the Federal Rural University of the Semi-Arid (Ufersa) (Latitude $5^{\circ} 03^{\prime}$, Longitude $37^{\circ} 23^{\prime} \mathrm{W}$; mean altitude $72 \mathrm{~m}$ ), in a Latosol Yellow Red Argisolic sandy loam soil (EMPRESA BRASILEIRA DE PESQUISA AGROPECUÁRIA - EMBRAPA, 2013) from June to November 2017. Soil chemical characteristics are displayed in Table 1.

Table 1. Chemical characterization of the soil at 0-20cm depth. Mossoró - RN. Ufersa 2017

\begin{tabular}{ccccccc}
\hline $\mathrm{pH}$ & $\mathrm{CE}$ & $\mathrm{P}^{1}$ & $\mathrm{~K}^{+}$ & $\mathrm{Na}^{+}$ & $\mathrm{Ca}^{2+}$ & $\mathrm{Mg}^{+2}$ \\
\hline (water) & $\mathrm{dS} \mathrm{m}^{-1}$ & $------------\mathrm{mg} \mathrm{dm}^{-3}$ & ------------ & $-----\mathrm{Cmol}_{\mathrm{c}} \mathrm{dm}^{-3}$------ \\
\hline 5.10 & 0.03 & 6.70 & 32.20 & 4.80 & 0.80 & 0.50 \\
\hline
\end{tabular}

Note: ${ }^{1}$ Mehlich extractor.

Source: Own authorship.

The climate in the region, according to Köppen's classification, is BSwh', dry and very hot (CARMO FILHO et al. 1991). Climate data for the experiments period are displayed in Table 2.

Table 2. Climate data from the study area. Mossoró - RN. Ufersa 2017

\begin{tabular}{|c|c|c|c|c|c|c|c|c|c|}
\hline \multirow[t]{2}{*}{ Month } & \multicolumn{3}{|c|}{ Air temperature $\left({ }^{\circ} \mathrm{C}\right)$} & \multirow{2}{*}{$\begin{array}{c}\text { Thermal } \\
\text { amplitude } \\
\left({ }^{\circ} \mathrm{C}\right)\end{array}$} & \multicolumn{3}{|c|}{ Air relative humidity (\%) } & \multirow[b]{2}{*}{$\begin{array}{l}\text { Rainfall } \\
\text { (mm) }\end{array}$} & \multirow{2}{*}{$\begin{array}{c}\text { Solar } \\
\text { radiation } \\
\left(\mathrm{W} / \mathrm{m}^{2}\right)\end{array}$} \\
\hline & Mean & $\begin{array}{c}\text { Maxim } \\
\text { um }\end{array}$ & Minimum & & Mean & Maximum & Minimum & & \\
\hline June & 27.72 & 36.31 & 20.65 & 15.66 & 70.79 & 97.30 & 31.50 & 14.20 & 211.31 \\
\hline July & 26.99 & 35.64 & 19.10 & 16.04 & 66.86 & 98.20 & 29.30 & 58.60 & 198.87 \\
\hline August & 27.45 & 37.92 & 19.37 & 18.55 & 64.94 & 93.50 & 29.00 & 0.20 & 254.67 \\
\hline September & 27.96 & 38.45 & 19.56 & 18.84 & 60.42 & 90.80 & 24.50 & 2.40 & 263.64 \\
\hline October & 28.32 & 38.64 & 21.03 & 17.61 & 64.19 & 91.40 & 29.30 & 0.80 & 267.05 \\
\hline November & 28.04 & 37.15 & 20.96 & 16.19 & 67.75 & 91.50 & 32.90 & 0.60 & 277.66 \\
\hline
\end{tabular}

Source: Meteorological Station from Rafael Fernandes Experimental Farm 2018.

\section{Treatments and Experimental Design}

The experimental design was complete randomized blocks, with ten treatments and four repetitions. Treatments consisted of ten carrot cultivars four of which were open-pollinated varieties: Brasília (TopSeed®), BRS Planalto (ISLA®), Suprema (ISLA®) and Kuronan (ISLA $\left.{ }^{\circledR}\right)$; and six were hybrid cultivars: Nativa (Sakata $\left.{ }^{\circledR}\right)$, Mariana (Feltrin $\left.{ }^{\circledR}\right)$, Melinda (Feltrin $\left.{ }^{\circledR}\right)$, Amanda, (Agristar®), Francine (Agristar $\left.{ }^{\circledR}\right)$ and Érica (Agristar ${ }^{\circledR}$ ). The ten cultivars were sown in two dates: June and July. Each experimental unity was composed of a plot with $30 \times 1.0 \mathrm{~m}$, with six rows of plants, spaced $0.15 \times 0.06 \mathrm{~m}$, making a total area of $30 \mathrm{~m}^{2}$ and a population of approximately 780,000 plants per hectare, in which the useful area was the four central rows, dismissing one row of plants in each extremity.

\section{Experiment Implementation}

Soil tillage consisted of ploughing, harrowing and lifting of the plant beds to $0,20 \mathrm{~m}$ height, approximately.

Planting fertilization was performed based on soil analysis. Previously to sowing, 120 $\mathrm{kg} \mathrm{ha}^{-1}$ of $\mathrm{N}, 460 \mathrm{~kg} \mathrm{ha}^{-1}$ of $\mathrm{P}_{2} \mathrm{O}_{5}$ and $110 \mathrm{~kg} \mathrm{ha}^{-1}$ of $\mathrm{S}$ were applied to the seed beds. 
Further fertilizations were performed via fertirrigation, from the $15^{\text {th }}$ through the $90^{\text {th }}$ days after germination apllying $135 \mathrm{~kg} \mathrm{ha}^{-1}$ of nitrogen and $172 \mathrm{~kg} \mathrm{ha}^{-1}$ of potassium. Micronutrients were applied using Rexolin ${ }^{\circledR}$ as source $\left(1.6 \% \mathrm{~K}_{2} \mathrm{O} 1.28 \% \mathrm{~S}, 0.86 \% \mathrm{Mg} 2.1 \%\right.$ $\mathrm{B}, 0.36 \% \mathrm{Cu} 2.66 \% \mathrm{Fe} 2.48 \% \mathrm{Mn}, 0.036 \% \mathrm{Mo}$ and $3.38 \% \mathrm{Zn}$ ).

Sowing was performed manually in the transverse direction of the seed beds in pits of approximately $2.0 \mathrm{~cm}$ deep, spaced $6.0 \mathrm{~cm}$ from each other, putting from three to four seeds per pit.

The irrigation system applied was, during the first 15 days after sowing, micro sprinkler and, after the first 15 days until the end of the crop cycle, via drip irrigation. The drip irrigation system consisted of three hoses per seed bed, spaced $15.0 \mathrm{~cm}$ between hoses and drippers spaced at each $20.0 \mathrm{~cm}$. Irrigation was done daily based on the carrot crop evapotranspiration (ALLEN et al., 2006)

Whenever it was necessary, manual weeding was performed.

Harvest was carried out when the oldest leaves yellowed and dried and the younger leaves bended, which happened at around 120 days after sowing.

\section{Characteristics Evaluated}

- Plant height and number of leaves $(\mathrm{cm})$ : Fifteen plants per plot were measured from soil level to the top of the highest leaf. Measurement was done, approximately, 80 days after the sowing of each experiment.

- Root fresh and dry weight $(\mathrm{g})$ : At harvest 10 roots classified as commercial from each experimental plot were washed, split into tops and root and then weighed. After that, they were stored in paper bags and put into a forced circulation oven at $65^{\circ} \mathrm{C}$, until it reached constant weight. After that it was weighted in a precision balance.

- Nutrients accumulation (g plant $\left.{ }^{-1}\right)$ : After dry matter was determined, the plants were milled and the macronutrients content $(\mathrm{N}, \mathrm{P}, \mathrm{Ca}, \mathrm{K}, \mathrm{Mg})$ was determined according to Tedesco et al. (1995) methodology.

\section{Statistical Analysis}

Variance analysis of the evaluated characteristics was performed for each experiment separately. Following, joint analysis of the experiments was performed for those characteristics that passed the homogeneity test (PIMENTEL-GOMES, 2009).

Statistical analysis was performed using the statistical software SISVAR v 5.3 (FERREIRA, 2011). The Scott-Knott test at 5\% probability was used for means comparison.

\section{RESULTS AND DISCUSSION}

\section{Plant Growth}

There was no significant interaction between Cultivars and Planting dates for the characteristics related to plant growth (Table 3). Root and plant dry matter content did not vary significantly at a 5\% level, while the dry matter content on the tops did. Open-pollinated 
cultivars obtained the highest dry matter content on the leaves, with emphasis on the cultivars BRS Planalto and Kuronan. During planting date two it was observed the highest dry matter content in the leaves.

Table 3. Number of leaves, plant height $(\mathrm{cm})$ and dry matter content in the leaves $(\mathrm{g})$. Mossoró - RN. Ufersa 2017.

\begin{tabular}{lrrr}
\hline Cultivars & N. of leaves & Plant height $(\mathrm{cm})$ & LDMC $(\mathrm{g})$ \\
\hline Amanda $(\mathrm{H})$ & $9.65 \mathrm{a}$ & $43.92 \mathrm{~b}$ & $10.01 \mathrm{~b}$ \\
Brasília $(\mathrm{OP})$ & $10.40 \mathrm{a}$ & $45.54 \mathrm{~b}$ & $11.94 \mathrm{a}$ \\
BRS Planalto $(\mathrm{OP})$ & $9.42 \mathrm{a}$ & $48.23 \mathrm{a}$ & $12.36 \mathrm{a}$ \\
Érica $(\mathrm{H})$ & $9.40 \mathrm{a}$ & $44.54 \mathrm{~b}$ & $10.49 \mathrm{~b}$ \\
Francine $(\mathrm{H})$ & $9.02 \mathrm{a}$ & $46.03 \mathrm{~b}$ & $8.99 \mathrm{~b}$ \\
Kuronan $(\mathrm{OP})$ & $9.87 \mathrm{a}$ & $45.70 \mathrm{~b}$ & $12.18 \mathrm{a}$ \\
Mariana $(\mathrm{H})$ & $9.29 \mathrm{a}$ & $47.69 \mathrm{a}$ & $10.17 \mathrm{~b}$ \\
Melinda $(\mathrm{H})$ & $8.65 \mathrm{~b}$ & $42.53 \mathrm{~b}$ & $8.68 \mathrm{~b}$ \\
Nativa $(\mathrm{H})$ & $7.94 \mathrm{~b}$ & $49.25 \mathrm{a}$ & $8.63 \mathrm{~b}$ \\
Suprema $($ OP) & $9.42 \mathrm{a}$ & $43.55 \mathrm{~b}$ & $11.69 \mathrm{a}$ \\
\hline Planting dates & N. of leaves & Plant height $(\mathrm{cm})$ & LDMC $(\mathrm{g})$ \\
\hline June (Planting date one) & $9.14 \mathrm{a}$ & $50.58 \mathrm{a}$ & $9.58 \mathrm{~b}$ \\
July (Planting date two) & $9.47 \mathrm{a}$ & $40.81 \mathrm{~b}$ & $11.44 \mathrm{a}$ \\
\hline
\end{tabular}

Note: $\mathrm{H}=$ Hybrid; $\mathrm{OP}=$ Open pollinated cultivar. * Means followed by the same letter do not differ statistically from one another by the Scott-Knott test at 5\% probability level. LDMC: Dry matter content in the leaves.

Source: Own authorship.

Concerning the number of leaves, the mean number of leaves of the cultivars Melinda and Nativa differed from the others and were those with the lowest number of leaves. Despite being a cultivar with great plant height, the Nativa cultivar was the one with the lowest number of leaves.

Table 4. Root fresh weight (g). Mossoró - RN. Ufersa 2017

\begin{tabular}{lcc}
\hline \multirow{2}{*}{ Cultivars } & \multicolumn{2}{c}{ Planting dates } \\
\cline { 2 - 3 } & $\begin{array}{c}\text { June } \\
\text { Planting date one }\end{array}$ & $\begin{array}{c}\text { July } \\
\text { Planting date two }\end{array}$ \\
\hline Amanda (H) & $133.7 \mathrm{aA}$ & $120.1 \mathrm{aA}$ \\
Brasília (OP) & $101.4 \mathrm{bA}$ & $77.2 \mathrm{bB}$ \\
BRS Planalto (OP) & $86.8 \mathrm{bA}$ & $100.5 \mathrm{aA}$ \\
Érica (H) & $117.6 \mathrm{aA}$ & $111.6 \mathrm{aA}$ \\
Francine (H) & $125.2 \mathrm{aA}$ & $85.4 \mathrm{bB}$ \\
Kuronan (OP) & $100.5 \mathrm{bA}$ & $75.7 \mathrm{bB}$ \\
Mariana (H) & $74.9 \mathrm{bA}$ & $81.6 \mathrm{bA}$ \\
Melinda (H) & $87.1 \mathrm{bB}$ & $117.5 \mathrm{aA}$ \\
Nativa (H) & $117.1 \mathrm{aA}$ & $119.4 \mathrm{aA}$ \\
Suprema (OP) & $109.7 \mathrm{aA}$ & $88.4 \mathrm{bB}$
\end{tabular}

Note: $\mathrm{H}=$ Hybrid; $\mathrm{OP}=$ Open pollinated cultivar. * Means followed by the same letter do not differ statistically from one another by the Scott-Knott test at 5\% probability level.

Source: Own authorship. 
Regarding the root fresh weight (Table 4), it was observed a general decrease between cultivars from planting date one to planting date two. However, only the open pollinated cultivars showed a statistically significant decrease. Overall, the hybrid cultivars showed a non-significant decrease in fresh weight between planting dates, except for the Melinda cv., which had an increase in fresh weight.

\section{Nutrient Accumulation}

Nitrogen accumulation in the roots was affected by the interaction between cultivars and planting dates and the accumulation of this nutrient in the roots did not differ amongst cultivars in the second Planting date (Table 5). For the plants sown in June (planting date one) the cultivars BRS Planalto and Mariana differed from the others and were those with the lowest accumulation of $\mathrm{N}$ in the roots.

Table 5. Nitrogen accumulation in the roots $\left(\mathrm{mg}\right.$ plant $\left.^{-1}\right)$. Mossoró $-\mathrm{RN}$. Ufersa 2017

\begin{tabular}{lcc}
\hline \multirow{2}{*}{ Cultivars } & \multicolumn{2}{c}{ Planting dates } \\
\cline { 2 - 3 } & $\begin{array}{c}\text { June } \\
\text { Planting date one }\end{array}$ & $\begin{array}{c}\text { July } \\
\text { Planting date two }\end{array}$ \\
\hline Amanda $(\mathrm{H})$ & $140.62 \mathrm{aA}$ & $137.63 \mathrm{aA}$ \\
Brasília $(\mathrm{OP})$ & $128.27 \mathrm{aA}$ & $71.92 \mathrm{aB}$ \\
BRS Planalto $(\mathrm{OP})$ & $91.02 \mathrm{bA}$ & $110.77 \mathrm{aA}$ \\
Erica $(\mathrm{H})$ & $169.40 \mathrm{aA}$ & $127.22 \mathrm{aA}$ \\
Francine $(\mathrm{H})$ & $136.52 \mathrm{aA}$ & $120.57 \mathrm{aA}$ \\
Kuronan $(\mathrm{OP})$ & $112.52 \mathrm{aA}$ & $137.77 \mathrm{aA}$ \\
Mariana $(\mathrm{H})$ & $67.90 \mathrm{bB}$ & $114.80 \mathrm{aA}$ \\
Melinda $(\mathrm{H})$ & $126.27 \mathrm{aA}$ & $95.37 \mathrm{aA}$ \\
Nativa $(\mathrm{H})$ & $151.35 \mathrm{aA}$ & $101.59 \mathrm{aB}$ \\
Suprema $(\mathrm{OP})$ & $119.45 \mathrm{aA}$ & $127.57 \mathrm{aA}$ \\
\hline
\end{tabular}

Note: $\mathrm{H}=$ Hybrid; $\mathrm{OP}=$ Open pollinated cultivar. *Means followed by the same letter do not differ statistically from one another, upper case in the rows and lower case in the columns by the Scott-Knott at 5\% probability. Source: Own authorship.

The accumulation of phosphorus in the leaf, root and total varied accordingly to the interaction between cultivars and planting dates (Table 6).

Regarding the accumulation of potassium, in the leaves it varied only according to the cultivar, while the accumulation in the root and total varied according to the interaction between cultivars and Planting dates (Table 7).

For the accumulation of $\mathrm{K}$ in the leaves, two distinct groups were formed. The first group was composed, exclusively, by open pollinated cultivars, with the highest means, and the second group was composed by the hybrid cultivars, with a lower $\mathrm{K}$ accumulation in the leaves.

Therefore, the difference between the cultivar that presented the lowest (Amanda) and highest accumulation of potassium in the leaves (Kuronan) was almost $150 \mathrm{mg} \mathrm{pl}^{-1}$. 
Table 6. Phosphorus accumulation in the leaves, root and total (mg plant $\left.{ }^{-1}\right)$. Mossoró $-\mathrm{RN}$. Ufersa 2017

\begin{tabular}{|c|c|c|c|c|c|c|}
\hline \multirow[b]{2}{*}{ Cultivars } & \multicolumn{2}{|c|}{ Leaf } & \multicolumn{2}{|c|}{ Root } & \multicolumn{2}{|c|}{ Total } \\
\hline & $\begin{array}{c}\text { June } \\
\text { Planting } \\
\text { date one }\end{array}$ & $\begin{array}{c}\text { July } \\
\text { Planting } \\
\text { date two }\end{array}$ & $\begin{array}{c}\text { June } \\
\text { Planting } \\
\text { date one }\end{array}$ & $\begin{array}{c}\text { July } \\
\text { Planting } \\
\text { date two }\end{array}$ & $\begin{array}{c}\text { June } \\
\text { Planting } \\
\text { date one }\end{array}$ & $\begin{array}{c}\text { July } \\
\text { Planting } \\
\text { date two }\end{array}$ \\
\hline $\operatorname{Amanda}(\mathrm{H})$ & $17.90 \mathrm{aA}$ & $27.39 \mathrm{aA}$ & $61.27 \mathrm{aA}$ & $44.28 \mathrm{aA}$ & $79.17 \mathrm{aA}$ & $71.67 \mathrm{aA}$ \\
\hline Brasília (OP) & $16.66 \mathrm{aA}$ & $21.30 \mathrm{bA}$ & $58.20 \mathrm{aA}$ & $42.84 \mathrm{aA}$ & $74.87 \mathrm{aA}$ & $64.15 \mathrm{aA}$ \\
\hline BRS Planalto (OP) & $34.21 \mathrm{aA}$ & $24.24 \mathrm{bA}$ & $32.43 \mathrm{bA}$ & $53.10 \mathrm{aA}$ & $66.64 \mathrm{aA}$ & $77.35 \mathrm{aA}$ \\
\hline Érica $(\mathrm{H})$ & $13.50 \mathrm{aA}$ & $21.84 \mathrm{bA}$ & $73.56 \mathrm{aA}$ & $43.04 \mathrm{aB}$ & $87.06 \mathrm{aA}$ & $64.89 \mathrm{aA}$ \\
\hline Francine $(\mathrm{H})$ & $12.20 \mathrm{aA}$ & $17.78 \mathrm{bA}$ & $77.74 \mathrm{aA}$ & $26.25 \mathrm{aB}$ & $89.94 \mathrm{aA}$ & $44.04 \mathrm{bB}$ \\
\hline Kuronan (OP) & $20.57 \mathrm{aB}$ & $36.10 \mathrm{aA}$ & $40.72 \mathrm{bA}$ & $31.67 \mathrm{aA}$ & $61.29 \mathrm{aA}$ & $67.78 \mathrm{aA}$ \\
\hline $\operatorname{Mariana}(\mathrm{H})$ & $13.88 \mathrm{aB}$ & $37.45 \mathrm{aA}$ & $30.83 \mathrm{bA}$ & $33.30 \mathrm{aA}$ & $44.71 \mathrm{aA}$ & $70.75 \mathrm{aA}$ \\
\hline Melinda $(\mathrm{H})$ & $26.11 \mathrm{aA}$ & $14.03 \mathrm{bA}$ & $42.73 \mathrm{bA}$ & $26.16 \mathrm{aA}$ & $68.84 \mathrm{aA}$ & $40.20 \mathrm{bB}$ \\
\hline Nativa $(\mathrm{H})$ & $13.98 \mathrm{aA}$ & $15.58 \mathrm{bA}$ & $55.54 \mathrm{aA}$ & $22.08 \mathrm{aB}$ & $69.53 \mathrm{aA}$ & $37.67 \mathrm{bB}$ \\
\hline Suprema (OP) & $17.52 \mathrm{aA}$ & $30.32 \mathrm{aA}$ & $63.47 \mathrm{aA}$ & $39.45 \mathrm{aB}$ & $80.99 \mathrm{aA}$ & $69.77 \mathrm{aA}$ \\
\hline
\end{tabular}

Note: $\mathrm{H}=$ Hybrid; $\mathrm{OP}=$ Open pollinated cultivar. *Means followed by the same letter do not differ statistically from one another, upper case in the rows and lower case in the columns by the Scott-Knott at 5\% probability. Source: Own authorship.

Table 7. Potassium accumulation in the leaves, root and total (mg plant $\left.{ }^{-1}\right)$. Mossoró - RN. Ufersa 2017

\begin{tabular}{lccccc}
\hline & & \multicolumn{2}{c}{ Root } & \multicolumn{2}{c}{ Total } \\
\cline { 3 - 6 } Cultivars & Leaf & $\begin{array}{c}\text { June } \\
\text { Planting } \\
\text { date one }\end{array}$ & $\begin{array}{c}\text { July } \\
\text { Planting } \\
\text { date two }\end{array}$ & $\begin{array}{c}\text { June } \\
\text { Planting } \\
\text { date one }\end{array}$ & $\begin{array}{c}\text { July } \\
\text { Planting } \\
\text { date two }\end{array}$ \\
\hline Amanda $(\mathrm{H})$ & $306.93 \mathrm{~b}$ & $565.44 \mathrm{aA}$ & $358.57 \mathrm{bB}$ & $926.37 \mathrm{aA}$ & $611.50 \mathrm{bB}$ \\
Brasília $(\mathrm{OP})$ & $429.96 \mathrm{a}$ & $483.63 \mathrm{aA}$ & $475.57 \mathrm{aA}$ & $966.92 \mathrm{aB}$ & $852.22 \mathrm{aB}$ \\
BRS Planalto $(\mathrm{OP})$ & $425.05 \mathrm{a}$ & $382.80 \mathrm{aB}$ & $674.28 \mathrm{aA}$ & $717.29 \mathrm{bB}$ & $1189.91 \mathrm{aA}$ \\
Érica $(\mathrm{H})$ & $348.24 \mathrm{~b}$ & $519.08 \mathrm{aA}$ & $428.11 \mathrm{bA}$ & $878.57 \mathrm{aB}$ & $765.10 \mathrm{bB}$ \\
Francine $(\mathrm{H})$ & $284.41 \mathrm{~b}$ & $517.78 \mathrm{aA}$ & $314.01 \mathrm{bB}$ & $813.89 \mathrm{aB}$ & $586.72 \mathrm{bB}$ \\
Kuronan $(\mathrm{OP})$ & $448.89 \mathrm{a}$ & $459.00 \mathrm{aA}$ & $538.26 \mathrm{aA}$ & $912.50 \mathrm{aB}$ & $982.54 \mathrm{aB}$ \\
Mariana $(\mathrm{H})$ & $357.68 \mathrm{~b}$ & $318.42 \mathrm{aB}$ & $483.58 \mathrm{aA}$ & $606.08 \mathrm{bB}$ & $911.30 \mathrm{aA}$ \\
Melinda $(\mathrm{H})$ & $244.67 \mathrm{~b}$ & $408.52 \mathrm{aA}$ & $387.81 \mathrm{bA}$ & $657.60 \mathrm{bB}$ & $628.07 \mathrm{bB}$ \\
Nativa $(\mathrm{H})$ & $353.86 \mathrm{~b}$ & $518.65 \mathrm{aA}$ & $365.08 \mathrm{bA}$ & $882.89 \mathrm{aB}$ & $708.56 \mathrm{bB}$ \\
Suprema $(\mathrm{OP})$ & $432.80 \mathrm{a}$ & $466.66 \mathrm{aA}$ & $537.75 \mathrm{aA}$ & $881.78 \mathrm{aB}$ & $988.25 \mathrm{aB}$ \\
\hline
\end{tabular}

Note: $\mathrm{H}=$ Hybrid; $\mathrm{OP}=$ Open pollinated cultivar. *Means followed by the same letter do not differ statistically from one another, upper case in the rows and lower case in the columns by the Scott-Knott at $5 \%$ probability. Source: Own authorship.

For the accumulation of $\mathrm{K}$ in the roots, it was also observed the formation of two groups of cultivars. However, in addition to the open pollinated varieties, the Mariana hybrid also integrated the group of carrots with the largest accumulations of $\mathrm{K}$. The second group was formed by the hybrid cultivars, except Mariana. 
Regarding the total accumulation of potassium in the plant, for the cultivation carried out in June, the cultivars Mariana and Melinda did not differ between themselves and were those with the lowest accumulations of potassium. The other cultivars did not differ between themselves.

Concerning the total accumulation of $\mathrm{K}$ in the plants sown in July, it was noticed a greater variation in the means between the cultivars. Amanda, Erica, Francine, Melinda and Nativa presented the lowest accumulations of K. The remaining cultivars did not differ statistically and presented means varying between 852.22 (Brasília) and 1,189.92 mg plant ${ }^{-1}$ (BRS Planalto).

Regarding the accumulation of calcium in the leaves, root and total, it did not vary significantly for any of the sources of variation evaluated.

The accumulation of magnesium in the leaves, root and total varied as a function of the interaction between cultivars and planting dates (Table 8).

Table 8. Accumulation of Magnesium in the leaves, root and total (mg plant $\left.{ }^{-1}\right)$. Mossoró RN. Ufersa 2017

\begin{tabular}{lcccccc}
\hline & \multicolumn{2}{c}{ Leaf } & \multicolumn{2}{c}{ Root } & \multicolumn{2}{c}{ Total } \\
\cline { 2 - 7 } Cultivars & $\begin{array}{c}\text { June } \\
\text { Planting } \\
\text { date one }\end{array}$ & $\begin{array}{c}\text { July } \\
\text { Planting } \\
\text { date two }\end{array}$ & $\begin{array}{c}\text { June } \\
\text { Planting } \\
\text { date one }\end{array}$ & $\begin{array}{c}\text { July } \\
\text { Planting } \\
\text { date two }\end{array}$ & $\begin{array}{c}\text { June } \\
\text { Planting } \\
\text { date one }\end{array}$ & $\begin{array}{c}\text { Pulanting } \\
\text { date two }\end{array}$ \\
\hline Amanda (H) & $11.56 \mathrm{bA}$ & $8.49 \mathrm{bA}$ & $6.33 \mathrm{bA}$ & $5.52 \mathrm{aA}$ & $17.90 \mathrm{bA}$ & $14.01 \mathrm{bA}$ \\
Brasília (OP) & $15.01 \mathrm{aA}$ & $13.93 \mathrm{aA}$ & $15.55 \mathrm{aA}$ & $5.07 \mathrm{aB}$ & $30.56 \mathrm{aA}$ & $19.01 \mathrm{aB}$ \\
BRS Planalto (OP) & $12.14 \mathrm{bB}$ & $19.42 \mathrm{aA}$ & $8.05 \mathrm{bA}$ & $7.82 \mathrm{aA}$ & $20.19 \mathrm{bA}$ & $27.24 \mathrm{aA}$ \\
Érica (H) & $18.10 \mathrm{aA}$ & $8.32 \mathrm{bB}$ & $5.83 \mathrm{bA}$ & $3.60 \mathrm{aA}$ & $23.93 \mathrm{aA}$ & $11.92 \mathrm{bB}$ \\
Francine (H) & $18.21 \mathrm{aA}$ & $7.99 \mathrm{bB}$ & $4.88 \mathrm{bA}$ & $3.89 \mathrm{aA}$ & $23.10 \mathrm{aA}$ & $11.89 \mathrm{bB}$ \\
Kuronan (OP) & $9.73 \mathrm{bA}$ & $14.46 \mathrm{aA}$ & $6.77 \mathrm{bA}$ & $5.53 \mathrm{aA}$ & $16.50 \mathrm{bA}$ & $19.99 \mathrm{aA}$ \\
Mariana (H) & $8.55 \mathrm{bA}$ & $9.40 \mathrm{bA}$ & $4.62 \mathrm{bA}$ & $5.68 \mathrm{aA}$ & $13.18 \mathrm{bA}$ & $15.09 \mathrm{bA}$ \\
Melinda (H) & $9.73 \mathrm{bA}$ & $8.91 \mathrm{bA}$ & $4.79 \mathrm{bA}$ & $5.46 \mathrm{aA}$ & $14.52 \mathrm{bA}$ & $14.38 \mathrm{bA}$ \\
Nativa (H) & $10.41 \mathrm{bA}$ & $7.58 \mathrm{bA}$ & $8.72 \mathrm{bA}$ & $3.16 \mathrm{aB}$ & $19.14 \mathrm{bA}$ & $10.75 \mathrm{bB}$ \\
Suprema (OP) & $14.22 \mathrm{aA}$ & $14.83 \mathrm{aA}$ & $7.14 \mathrm{bA}$ & $6.06 \mathrm{aA}$ & $21.36 \mathrm{aA}$ & $20.90 \mathrm{aA}$ \\
\hline
\end{tabular}

Note: $\mathrm{H}=$ Hybrid; $\mathrm{OP}=$ Open pollinated cultivar. *Means followed by the same letter do not differ statistically from one another, upper case in the rows and lower case in the columns by the Scott-Knott at 5\% probability. Source: Own authorship.

There were two distinct groups of cultivars for the accumulation of $\mathrm{Mg}$ in the leaves in both planting dates. In season 1, the BRS Planalto and Kuronan varieties and the Amanda, Mariana, Melinda and Nativa hybrids did not differ statistically and composed the group of cultivars with lower $\mathrm{Mg}$ accumulation in the plant, whereas in season 2, this group consisted exclusively of the hybrid cultivars.

The accumulation of $\mathrm{Mg}$ in the root did not vary significantly between cultivars during the second planting date. In Season 1, only the cultivar Brasilia differed significantly from the others, being the cultivar that accumulated the most magnesium in this planting date. 
Alongside the hybrid cultivar Nativa, Brasilia presented a negative variation in the accumulation of $\mathrm{Mg}$ in the roots during season 2.

The total accumulation of magnesium in the plants also had the formation of two groups of cultivars. Only the BRS Planalto cultivar showed an increase in Mg accumulation between planting dates. The Érica and Francine cultivars presented a decrease in nutrient accumulation in the leaves between seasons one and two. The other cultivars did not present significant variation in the accumulation of $\mathrm{Mg}$ in the leaves between the planting dates.

The cultivars Brasília, Érica, Francine, Mariana and Nativa showed a decrease in the accumulation of total magnesium between the planting dates.

Aquino et al. (2015) also found that there was no effect of the cultivars on the dry matter contents in the roots. The values found by Resende et al. (2016) regarding leaves dry matter content (15.5 $\mathrm{g} \mathrm{plant}^{-1}$ in the tops and $31.1 \mathrm{~g} \mathrm{plant}^{-1}$ in the roots) was slightly higher than the one found in this experiment, probably due to climatic and soil conditions found in the different study areas.

Plant's mean height ranged from $49.25 \mathrm{~cm}$ (Nativa) to $42.53 \mathrm{~cm}$ (Melinda). This behavior shows a higher accumulation of dry matter in the leaves won't necessarily result in higher plants.

Amongst planting dates it was observed that greater heights were obtained by those plants sown in June, with a difference of about $10 \mathrm{~cm}$ between planting dates. It probably happened because of the climatic factors. In July it was observed a total rainfall of $59 \mathrm{~mm}$, which is above the mean for this month in the study area. The rainfall volume associated with the increase in the minimum temperatures and solar radiation during the cycle of the plants sown in July, might have interfered in their growth in the early stages of plant development, causing the diminishment in plant height.

It was observed that the different Planting dates did not affect the number of leaves and therefore this characteristic is rather related to genetic traits of the different cultivars than to climate. This result is similar to the one found by Teófilo et al. (2009).

The decrease in root fresh weight from planting date one to 2 is, once again, probably related with the climatic conditions to which the plants sown in July were submitted during their cycle (i.e. rainfall in July and high solar radiation from August to November, as well as the increase in the minimum temperatures during the same period).

Between Planting dates it was observed a variation in the accumulation of $\mathrm{N}$ on the cultivars Brasília, Mariana and Nativa, in which Brasília and Nativa presented a decrease and Mariana presented an increase in $\mathrm{N}$ in the root. Therefore, we observe that the accumulation of nitrogen in carrot roots is related both with genetic characteristics and climatic conditions, as has been previously observed by Aquino et al. (2015).

Aquino et al. (2015) observed a mean of $21.7 \mathrm{~g} \mathrm{~kg}^{-1}$ of $\mathrm{N}$ in the roots and $15.0 \mathrm{~g} \mathrm{~kg}^{-1}$ of $\mathrm{N}$ in the leaves.

In general, the accumulation of nitrogen in the roots observed in this work was inferior to the one found by Cecílio Filho and Peixoto (2005). This difference might have occurred 
due to differences in the fertilization management and climatic characteristics of the study area.

The cultivars Amanda, Kuronan, Mariana and Suprema were those with the highest accumulations of $\mathrm{P}$ in the leaves. The nutrient accumulation in the roots, in Planting date two, did not vary significantly between cultivars, while in Planting date one it was observed the formation of two distinct groups: the first one formed by the cultivars Amanda, Brasília, Érica, Francine, Nativa and Suprema, with the highest accumulations of this nutrient; the second one was formed by BRS Planalto, Kuronan and Mariana, with lower accumulations of $\mathrm{P}$ in the root.

Concerning the accumulation of $\mathrm{P}$ in the whole plant, in planting date one there was no significant difference between the cultivars. In planting date two, the cultivars Francine, Melinda and Nativa were those with the lowest accumulations of $\mathrm{P}$ in the plant. Taking into consideration that these two cultivars were also the ones which presented the highest plants (Table 3), it implies that these cultivars are the most efficient in the phosphorus usage.

Regarding the planting dates, the accumulation of phosphorus in the whole plant decreased for the cultivars Francine, Melinda and Nativa.

Concerning the accumulation of potassium, the results found in this study are consistent with the means obtained by Cecílio Filho and Peixoto (2013) who reported that an accumulation of $381.2 \mathrm{mg}_{\text {plant }}{ }^{-1} \mathrm{~K}$ in the leaves and $525.2 \mathrm{mg} \mathrm{plant}^{-1}$ in the roots. Aquino et al., (2015) observed a mean of $375.0 \mathrm{~g} \mathrm{~kg}^{-1}$ of $\mathrm{K}$ in the roots and $230.5 \mathrm{~g} \mathrm{~kg}^{-1}$ of $\mathrm{K}$ in the leaves. The difference in the results could be related both to edaphoclimatic conditions, fertilization management and the chosen cultivars.

Overall, the results obtained in this study for the accumulation of magnesium diverged from those obtained by Cecílio Filho and Peixoto (2013), who report that the accumulation of $\mathrm{Mg}$ in the leaves of Brasília was of $16.71 \mathrm{mg}$ plant $^{-1}$ and in the roots $20.9 \mathrm{mg} \mathrm{plant}^{-1}$. In this study, instead, it was observed a greater accumulation of $\mathrm{Mg}$ in the leaves. These results also diverge from those obtained by Souza et al. (2003).

However, the results obtained in this study are in agreement with Oliveira et al. (2006), who reported a bigger accumulation of $\mathrm{Mg}$ in the roots for the Brasilia carrot in Mossoró. This shows that the accumulation of $\mathrm{Mg}$ and its distribution in the carrot plant are conditioned by the environment and the agricultural management conditions, since Oliveira et al. (2006) and Souza and Resende (2003) tested the same cultivar, but in different study areas: the first in Mossoró and the second in the Federal District.

Overall, it has been seen that in July the nutrient accumulation was lower than in June and it influenced directly the decrease in root fresh weight in this period. As previously observed, the plants sown in July were submitted to climatic conditions that are known to be limiting to carrot's growth. This might have interfered in the physiology of the plant itself, since carrot is classified as a C3 plant and, therefore, is subject to photorespiration as well as photo-inhibition and the rise in solar radiation and the increase of minimum temperatures tend to provoke these physiological processes. Both of these processes directly affect the 
photosynthetic efficiency of $\mathrm{C} 3$ plants, reducing the efficiency of photosynthesis, thus impacting in its growth.

Finally, the results found in this study match the conclusions made by Aquino et al. (2015) which found that both the planting date and the cultivars exert influence in the nutrient contents in the leaves and roots of the carrot crop, and the extraction and exportation of nutrients by the carrot crop.

\section{CONCLUSION}

The different planting dates influenced the accumulation of nutrients in the different parts of the plant of the different cultivars, and also affected the growth characteristics of the plants.

The cultivation in June implied in a bigger accumulation of all nutrients, except potassium.

The hybrid cultivars presented nutritional demand similar or lower than that of the open pollinated cultivars, despite their lower dry matter content in the leaves.

In decreasing order, the nutrients that were accumulated the most in the plant were: $\mathrm{K}>\mathrm{N}>\mathrm{P}>\mathrm{Ca}>\mathrm{Mg}$.

\section{REFERENCES}

ALLEN, R. G.; PEREIRA, L. S.; RAES D.; SMITH, M. Evapotranspiración del cultivo: Guías para la determinación de los requerimentos de agua de los cultivos. [S. l.]: FAO, 56, 2006. 298 p.

ANUÁRIO BRASILEIRO DE HORTALIÇAS - ABH. Brazilian Vegetable Yearbook. Santa Cruz do Sol: Gazeta, 2016. 68 p.

AQUINO, R. F. B. A.; ASSUNÇÃO, N. S.; AQUINO, L. A.; AQUINO, P. M.; GUILHERME, A.; CARVALHO, A. M. X. Nutrient demand by the carrot crop is influenced by the cultivar. Revista Brasileira de Ciencias do Solo, Viçosa, v. 39, n. 2, p.541-552, 2015.

CARMO FILHO, F.; ESPÍNOLA SOBRINHO, J.; MAIA NETO, J. M. Dados meteorológicos de Mossoró (Jan. 1988 a Dez. 1990). Mossoró: ESAM/FGD, 1991. 46 p. (Coleção Mossoroense)

CECÍlLIO FILHO, A. B.; PEIXOTO, F. C. Acúmulo e exportação de nutrientes em cenoura 'Forto'. Revista Caatinga, Mossoró, v. 26, n. 1, p.64-70, 2013.

CENTRO DE ESTUDOS AVANCADOS EM ECONOMIA APLICADA - CEPEA. Laboratório de informação. Piracicaba: Centro de Estudos Avancados em Economia Aplicada, 2010. Available at: http://www.cepea.esalq.usp.br/rrs.php. Last access: 28 June 2018. 
EMPRESA BRASILEIRA DE PESQUISA AGROPECUARIA - EMBRAPA, Centro Nacional de Pesquisa do solo. Sistema brasileiro de classificação de solos. 2. ed. Brasília: EMPRAPA, 2013. 286 p.

FERREIRA, D. F. SISVAR: programa estatístico, versão 5.3 (Build 75). Lavras: Universidade Federal de Lavras, 2007. Internet. Disponível em: https://des.ufla.br/ danielff/programas/sisvar.html. Acesso em: 05 Nov. 2021.

LUZ, J. M. Q.; SILVA JÚNIOR, J. A.; TEIXEIRA, M. S. S. C.; SILVA, M. A. D.; SEVERINO, G. M., MELO, B. Desempenho de cultivares de cenoura no verão e outonoinverno em Uberlândia-MG. Horticultura Brasileira, Brasília, v. 27, n. 1, p.96-99, 2009.

MENEGAZZO, T. M. Cenoura. Revista Hortifruti Brasil, [s. l.], v. 9, n. 93, p. 25, 2010.

MÜLLER, J. J. V. Aspectos do armazenamento de cenoura (Daucus carota L.). In: MÜLlER, J. J. V.; CASALI, V. W. D. (ed.). Seminários de Olericultura. v. 5, Viçosa: Imprensa Universitária, 1982. p.01-25.

OLIVEIRA, R. A.; MARROCOS, S. T. P.; LUCENA, R. R. M.; RAMOS, J. A. S.; GRANGEIRO, L. C. Acúmulo e exportação de nutrientes em cenoura. Horticultura Brasileira, Vitória da Conquista, v. 24, n. 2, p.01-05, 2006.

PIMENTEL-GOMES, F. Curso de estatística experimental. 15. ed. Piracicaba: ESALQ, 2009. $480 \mathrm{p}$.

RESENDE, G. M.; YURI J. E.; COSTA N. D.; MOTA J. H. Desempenho de cultivares de cenoura em sistema orgânico de cultivo em condições de temperaturas elevadas. Horticultura Brasileira, Brasília, v. 34, n. 1, p.121-125, 2016.

SOUZA A. F.; MESQUITA FILHO, M. V.; VIEIRA, J. V.; SOUZA, R. B.; MEIRELE, S. M. Teores de macronutrientes e produção de matéria seca em cenouras do Grupo Brasília, cultivadas em solos sob cerrado. Horticultura Brasileira, Brasília, v. 21, n. 2, p.1-4, 2003.

SOUZA J. L.; RESENDE P. Manual de horticultura orgânica. Viçosa, MG: Aprenda Fácil, 2003. $564 \mathrm{p}$.

TEDESCO, M. J.; BISSANI, C. A.; BOHNEN, H.; VOLKWEISS, S. J. Análises de solo, plantas e outros materiais. 2. ed. Porto Alegre: Universidade Federal do Rio Grande do Sul, 1995. 174 p. (Boletim técnico, 5)

TEÓFILO, T. M. S.; FREITAS, F. C. L.; NEGREIROS, M. Z.; LOPES, W. A. R.; VIEIRA, V. S. Crescimento de cultivares de cenoura nas condições de Mossoró - RN. Revista Caatinga, Mossoró, v. 22, n. 1, p.168-174, 2009. 